\section{Biochemical changes stimulated by accelerated aging in safflower seeds (Carthamus tinctorius L.)}

\author{
Sercan Önder ${ }^{1 *}$ iD, Muhammet Tonguç ${ }^{1}$ iD , Damla Güvercin² ${ }^{\mathbb{D}}$, Yaşar Karakurt ${ }^{1}$ iD
}

ABSTRACT: Seed vigor tests are used to estimate their quality. One of the most commonly used is the accelerated aging test (AA). The aim of the present study was to study the biochemical changes caused in the seeds and to determine their germination status after the AA. Six safflower genotypes were tested at $43^{\circ} \mathrm{C}$ and $45^{\circ} \mathrm{C}$ for $0,48,72,96$ and $120 \mathrm{~h}$, and germination percentage (GP), mean germination time (MGT) and normal seedling percentage (NSP) were evaluated to determine the aging reactions of the genotypes. During the $A A$ at $45^{\circ} \mathrm{C}$, the seeds quickly lost their germination ability after $48 \mathrm{~h}$; after $120 \mathrm{~h}$, the seeds lost their viability, remaining, however, still viable at $43^{\circ} \mathrm{C}$. Two genotypes that aged more (Linas and Olas) and less (Bayer-6 and Bayer-12) were chosen to examine the biochemical changes during the AA at $43{ }^{\circ} \mathrm{C}$. Eleven biochemical analysis were performed to understand physiological changes associated with the test. Total caratone, xanthophyll, phenolics, flavonoid, soluble protein, soluble sugars, oil and malondialdehyde contents were lower after 120 $\mathrm{h}$, compared to $0 \mathrm{~h}$. Reducing sugars and free fatty acids contents increased in the least and most aging genotypes. However, the total tocopherol content increased in the least aging genotypes and decreased in the most aging genotypes after $120 \mathrm{~h}$, compared to $0 \mathrm{~h}$. The results showed that the AA at $43^{\circ} \mathrm{C}$ was suitable to study the aging process in the safflower seeds. Besides, understanding the chemical changes was useful to elucidate the physiological basis of seed aging.

Index terms: germination, lipid peroxidation, oil seed, seed deterioration.

\section{Alterações bioquímicas estimuladas pelo envelhecimento acelerado em sementes de cártamo (Carthamus tinctorius L.)}

RESUMO: Testes de vigor de sementes são usados para estimar sua qualidade. Um dos mais utilizados é o teste de envelhecimento acelerado (EA). O objetivo do presente estudo foi estudar as alterações bioquímicas provocadas nas sementes e determinar seu status de germinação após o EA. Seis genótipos de cártamo foram testados a $43^{\circ} \mathrm{C}$ e $45^{\circ} \mathrm{C}$ por $0,48,72,96$ e $120 \mathrm{~h}$, e a porcentagem de germinação (PG), o tempo médio de germinação (TMG) e a porcentagem normal de plântulas (PNP) foram avaliados para determinar as reações de envelhecimento dos genótipos. Durante o EA a $45^{\circ} \mathrm{C}$, as sementes perderam rapidamente a capacidade de germinação após $48 \mathrm{~h}$; após $120 \mathrm{~h}$, as sementes perderam a viabilidade, mantendo-se, porém, ainda viáveis a $43^{\circ} \mathrm{C}$. Dois genótipos que envelheceram mais (Linas e Olas) e menos (Bayer-6 e Bayer-12) foram escolhidos para examinar as alterações bioquímicas durante o EA a $43{ }^{\circ} \mathrm{C}$. Onze análises bioquímicas foram realizadas para entender as alterações fisiológicas associadas ao teste. Os teores totais de caratona, xantofila, fenólicos, flavonoides, proteínas solúveis, açúcares solúveis, óleo e malondialdeído foram menores após 120 h, em comparação a 0 h. O teor de açúcares redutores e de ácidos graxos livres aumentou nos genótipos menos e mais envelhecidos. No entanto, o teor total de tocoferol aumentou nos genótipos com menor envelhecimento e diminuiu nos genótipos com maior envelhecimento após $120 \mathrm{~h}$, em comparação a $0 \mathrm{~h}$. Os resultados mostraram que o EA a $43^{\circ} \mathrm{C}$ foi adequado para estudar o processo de envelhecimento nas sementes de cártamo. Além disso, compreender as alterações químicas foi útil para elucidar a base fisiológica de envelhecimento das sementes.

Termos para indexação: germinação, peroxidação lipídica, oleaginosas, deterioração de sementes.
Journal of Seed Science, v.42, e202042015, 2020

http://dx.doi.org/10.1590/2317$1545 v 42227873$
*Corresponding author E-mail: sercanonder@outlook.com

Received: 8/25/2019

Accepted: 3/16/2020

${ }^{1}$ Isparta University of Applied Science, Faculty of Agricultural, Department of Agricultural Biotechnology - 32200, Isparta, Turkey.

${ }^{2}$ Suleyman Demirel University, Faculty of Arts and Sciences, Department of Biology - 32260, Isparta, Turkey. 


\section{INTRODUCTION}

Safflower (Carthamus tinctorius L.) is an important oilseed plant belonging to the Asteraceae. Safflower was used to obtain edible oil, biodiesel production, natural dyes and pharmaceuticals. In recent years, safflower started to become popular and world safflower acreage reached to 967.742 ha with a total production of 738.477 tons in 2017 (FAO, 2019).

Safflower has a regular flowering pattern with the formation of side branches on the main stem (Baydar and Ülger, 1998). Flowering period lasts between 10-40 days and, consequently, seeds of different sizes and quality are obtained from the plant. Since the seeds are stored after harvesting, deterioration and aging events occur within the seeds (Priestley, 1986). Seed degradation and aging affect their viability and vigor, leading to a decrease in their quality and even to death.

Seed vigor tests are used to estimate seed quality. One of the most commonly used is the accelerated aging (AA). In this test, seeds are artificially aged by exposure to high temperatures and high humidity for a certain period of time. The AA method was useful for estimating the vigor of various plants such as wheat (Ghahfarokhi et al., 2014), maize (Dias et al., 2015), soybean (Usha and Dadlani, 2015), canola (Yin et al., 2015), safflower (Demir, 2014) and sunflower (Kibinza et al., 2006; Balešević-Tubić et al., 2007), and the percent of emergence.

The main components of the seeds are lipids, carbohydrates, proteins and vitamins. The existence of these compounds in the seeds varies according to the plant species, environmental conditions and variety. Seed aging at the cellular level affects these reserves, resulting in cell membrane degradation, changes in energy metabolism, changes in the structure of proteins and enzymes, reduction in seed reserve utilization, degradation in lipid and carbohydrates and production of reactive oxygen species (ROS) and toxic compounds (Priestley, 1986). All these physiological reactions can lead to the deterioration in DNA structure and to the inhibition of RNA and protein synthesis. The loss of seed viability is the cumulative result of the deterioration effects in the cell. Components that accumulate in degraded or aged seeds also negatively affect the germination of non-degraded seeds (Priestley, 1986).

A large proportion of oilseed plants, such as safflower, are at risk of lipid peroxidation. During seed aging, the lipids in cells are degraded by enzymatic (lipases) lipid peroxidation or non-enzymatic (oxidative peroxidation) lipid peroxidation (Berger et al., 2001). Free radicals resulting from stress in seeds cause lipid peroxidation by acting on polyunsaturated fatty acids in membranes. Oxidative peroxidation is observed when the seed moisture content is low, but the ambient temperature is high. In enzymatic lipid peroxidation, lipases are activated when the water content of the seed is high and increases the effect of oxidative peroxidation.

Although safflower is becoming an important oilseed species, few studies were conducted to investigate safflower seed aging, vigor and viability. Although the seeds are classified as high or low vigor by using different vigor tests in seed groups of some plants, the information published in vigor tests used on safflower is still not enough. In recent years, the safflower cultivation increased the need of research on this plant.

The aim of the present study was to determine the germination responses of safflower genotypes after the accelerated aging test (AA), conducted under two different temperatures and periods, and to study the biochemical changes during the AA to elucidate the physiological basis of the seed aging in this species.

\section{MATERIAL AND METHODS}

\section{Plant material}

Six safflower genotypes (Bayer-6, Bayer-12, Dinçer, Montola 2000, Linas, Olas) was kindly provided by Sabri Erbaş from the Department of Field Crops. Seeds of all genotypes were stored at $4{ }^{\circ} \mathrm{C}$ until the experiments. 1000 -seed weights and moisture contents (MC) of the genotypes were determined according to ISTA (2009). Surface sterilization of the seeds was carried out in $1 \%$ sodium hypochlorite for ten minutes. 
Accelerated aging and germination test

The AA was performed as indicated by ISTA (2009) after the MC of all genotypes was adjusted to $12 \%$. Briefly, the $A A$ was carried out in sealed plastic boxes at $100 \%$ relative humidity under five time periods $(0,48,72,95$ and $120 \mathrm{~h}$ ) and two different temperatures $\left(43^{\circ} \mathrm{C}\right.$ and $\left.45^{\circ} \mathrm{C}\right)$ after the seeds were placed on a sieve. Each plastic box was used to include only one genotype and a single combination of temperature and time. After the test, two hundred seeds $(50 \times 4)$ from each genotype was put into filter papers, and the standard germination tests was conducted in a germination cabinet at $25 \pm 1{ }^{\circ} \mathrm{C}$ for fourteen days (ISTA, 2009). The rest of the seeds were stored in the refrigerator at $4{ }^{\circ} \mathrm{C}$ for biochemical analyses. Radicle formation of at least $2 \mathrm{~mm}$ in length was used as a germination criterion. Seeds were counted everyday to determine the germination percentage (GP), normal seedling percentage (NSP) and mean germination time (MGT) for fourteen days (ISTA, 2009). According to the results of the AA, the two most and the least aging genotypes were chosen and all biochemical analyses were performed using them.

\section{Biochemical analysis}

Total amount of carotene and xanthophylls contents were determined according to AOAC (1984). Absorbance values at $436 \mathrm{~nm}$ and $474 \mathrm{~nm}$ for carotenes and xanthophylls, respectively, were used to determine the total carotene and xanthophilic contents of the samples.

The extraction and quantification of total soluble phenolics and flavonoids was done according to Sakanaka et al. (2005). The absorbance value of the samples for total soluble phenolics was determined at $760 \mathrm{~nm}$, and 0.01-0.02-0.04-0.06-0.08 mM gallic acid standard was used for the standard curve. Absorbance at $510 \mathrm{~nm}$ was measured, and 0.2-0.4-0.6-0.8-1.0 $\mathrm{mM} \mathrm{(+)} \mathrm{-} \mathrm{catechin} \mathrm{concentrations} \mathrm{were} \mathrm{used} \mathrm{as} \mathrm{the} \mathrm{standard} \mathrm{curve} \mathrm{for} \mathrm{flavonoid}$ content determination.

Total soluble protein content was determined by Lowry-Hartree method (Hartree, 1972). 0.03-0.06-0.090.12-0.15 mg. mL ${ }^{-1}$ BSA was used to obtain the standard curve, and the absorbance values of the samples were determined at $650 \mathrm{~nm}$.

Total tocopherol content was determined according to modified Emmerie-Engel method as described in Backer et al. (1980). The absorbance values of the samples were determined at $522 \mathrm{~nm}$ after $60 \mathrm{~s}$, and 0.02-0.04-0.06-0.08-0.1 $\mathrm{mM} \alpha$-tocopherol was used to obtain the standard curve.

Total soluble sugars (TSS) and reducing sugars (RS) extraction was done as described in Tonguç et al. (2012). For TSS determination, phenol sulfiric acid assay (DuBois et al., 1956) and RS Nelson-Somogyi (Somogyi, 1952) methods were used. Standard curve was prepared using glucose at concentrations of 0.005-0.01-0.015-0.020-0.030 mg. $\mathrm{mL}^{-1}$.

Free fatty acids content determination was carried out as recommended by Lowry and Tinsley (1976). The standard curve was prepared using 2-4-6-8-10 mg. $\mathrm{mL}^{-1}$ oleic acid, and the absorbance of the samples were read at $715 \mathrm{~nm}$ with a spectrophometre. The total oil content of the genotypes was determined by nuclear magnetic resonance (NMR, Brükermq $_{\text {one }}$ ), and the results were expressed as \%.

Malondialdehyde (MDA) analysis was performed as described by Jiang et al. (2018). Absorbance at $532 \mathrm{~nm}$ was measured and subtracted from the absorbance at $600 \mathrm{~nm}$. The amount of MDA was calculated with an extinction coefficient of $155 \mathrm{~mm} . \mathrm{cm}^{-1}$.

\section{Statistical analysis}

The transformation was performed to normalize the germination test results. The obtained germination and biochemical data were analyzed with the Proc GLM procedure using SAS (1999) program. Each analysis was performed in tree replicates, and Duncan multiple comparison tests $(p \leq 0.05)$ was used to discriminate the differences between the means. 


\section{RESULTS AND DISCUSSION}

\section{Seed characteristics}

There were significant differences between the one thousand seed weight and the initial moisture content of the seeds (Table 1). $1000 \mathrm{~g}$ weight was found to be the highest in Bayer-6, while the lowest seed weight was found in Bayer-12. Montola 2000 and Dinçer had higher MC than the other genotypes. Olas had the lowest MC in the study, but there was no significant difference with Bayer-12.

The decline of seed germination, vigor and viability during $A A$

The germination tests were performed in seeds exposed to AA for $0,48,72,96$ and $120 \mathrm{~h}$, at both $43{ }^{\circ} \mathrm{C}$ and $45{ }^{\circ} \mathrm{C}$. Increased temperature and time led to significant reductions in the GPs of the genotypes (Table 2). Aging at $43{ }^{\circ} \mathrm{C}$ for $48 \mathrm{~h}$ only reduced GP of Olas, whereas AA at $45^{\circ} \mathrm{C}$ for $48 \mathrm{~h}$ reduced GPs of Dinçer, Linas and Olas significantly. Exposure to the test at $43{ }^{\circ} \mathrm{C}$ for $72 \mathrm{~h}$ reduced GP values of all genotypes, with the exception of Bayer-12, whose GP only declined significantly after $120 \mathrm{~h}$ exposure. On the other hand, exposure to the test at $45^{\circ} \mathrm{C}$ after $72 \mathrm{~h}$ reduced GP of all genotypes, and after 120 h exposure time, all genotypes lost their germination ability.

The increase in temperature and time during the AA caused increased MGT and decreased NSP values (Table 2). Regardless of time and temperature, MGT values increased in the test conditions. In all genotypes, the highest MGT was observed at $43{ }^{\circ} \mathrm{C}$ for $120 \mathrm{~h}$. Most of the abnormal seedlings did not have roots, or primary roots were short, or hypocotyls were deformed. Exposure to $43{ }^{\circ} \mathrm{C}$ for $48 \mathrm{~h}$ did not significantly affect NSP of the genotypes. However, exposure to $45^{\circ} \mathrm{C}$ temperature for $48 \mathrm{~h}$ reduced NSP of Dinçer, Olas and Linas. After $48 \mathrm{~h}$ duration time, NSP values of all genotypes reduced significantly for both temperatures.

Due to different $\mathrm{MC}$ of the seeds, seed MC was adjusted to approximately $12 \%$ to not to cause any difference during the AA. Seed MC and temperature are the most important factors affecting seed deterioration. As the seed MC and temperature increase, the rate of deterioration reactions in the seeds increase (McDonald and Kwong, 2005). A 1\% decrease in seed MC increases the seed life 2-fold, likewise $5^{\circ} \mathrm{C}$ reduction at the storage temperature increases the seed life twice (Harrington, 1972). In the current study, increase in MC of seeds aged at high temperature had a detrimental effect on germination and viability. High MC together with high temperatures could lead to a faster deterioration of the seeds during aging, leading to rapid viability decline in safflower (Demir, 2014) and sunflower (Kibinza et al., 2006). Our results show that as the temperature and time increased in the AA, the seeds' vigor and viability decreased.

When all germination index data were evaluated, seed vigor and viability were lost very quickly at $45^{\circ} \mathrm{C}$. Therefore, the $A A$ at $45^{\circ} \mathrm{C}$ was not suitable for determining biochemical changes in seeds. All biochemical analyses were performed on genotypes exposed to the AA at $43{ }^{\circ} \mathrm{C}$. Two genotypes that aged more (Linas and Olas) and less (Bayer- 6 and Bayer-12) were chosen to examine the biochemical changes during the $A A$ at $43^{\circ} \mathrm{C}$.

Table 1. One thousand seeds weight and seeds moisture content of the investigated safflower genotypes.

\begin{tabular}{cccc}
\hline Genotype & 1000 seed weight $(\mathrm{g})$ & Seeds MC (\%) & Seeds MC before AA (\%) \\
\hline Bayer- 6 & $48.99 \mathrm{a}$ & $4.65 \mathrm{~b}$ & 12.00 \\
Bayer-12 & $34.15 \mathrm{e}$ & $4.45 \mathrm{~cd}$ & 11.99 \\
Dinçer & $40.76 \mathrm{c}$ & $4.79 \mathrm{a}$ & 11.96 \\
Montola 2000 & $38.57 \mathrm{~d}$ & $4.81 \mathrm{a}$ & 12.02 \\
Linas & $44.32 \mathrm{~b}$ & $4.51 \mathrm{c}$ & 12.06 \\
Olas & $37.73 \mathrm{~d}$ & $4.38 \mathrm{~d}$ & 12.00 \\
\hline
\end{tabular}

a,b,c Means followed by the same letter (s) are not significantly different at $p \leq 0.05$. 
Table 2. Germination percentage (GP, \%), mean germination time (MGT, day) and normal seedling percentage (NSP, \%) after accelerated aging test (AA) and standard germination (SG) of safflower genotypes.

\begin{tabular}{|c|c|c|c|c|c|c|c|c|c|c|}
\hline \multirow{2}{*}{ Temp. } & \multirow{2}{*}{$\begin{array}{l}\text { Time } \\
\text { (hour) }\end{array}$} & \multicolumn{3}{|c|}{ Bayer-6 } & \multicolumn{3}{|c|}{ Bayer-12 } & \multicolumn{3}{|c|}{ Dinçer } \\
\hline & & GP & MGT & NSP & GP & MGT & NSP & GP & MGT & NSP \\
\hline \multirow{4}{*}{$43^{\circ} \mathrm{C}$} & 48 & $88.0 \mathrm{a}$ & $2.12 \mathrm{~cd}$ & $78.0 \mathrm{a}$ & $88.0 \mathrm{a}$ & $2.11 \mathrm{c}$ & $81.0 \mathrm{a}$ & $94.0 \mathrm{a}$ & $1.84 \mathrm{~d}$ & $86.5 \mathrm{a}$ \\
\hline & 72 & $70.5 \mathrm{~b}$ & $2.20 \mathrm{~cd}$ & $55.5 \mathrm{bc}$ & $80.0 \mathrm{a}$ & $2.14 \mathrm{c}$ & $72.0 \mathrm{~b}$ & $80.5 b$ & $1.52 \mathrm{~d}$ & $57.5 d$ \\
\hline & 96 & $62.0 \mathrm{c}$ & $3.62 b$ & $52.0 \mathrm{c}$ & $78.0 \mathrm{a}$ & $3.65 b$ & $69.5 \mathrm{~b}$ & $73.5 \mathrm{c}$ & $2.99 \mathrm{~b}$ & $67.5 \mathrm{c}$ \\
\hline & 120 & $39.0 \mathrm{e}$ & $4.38 \mathrm{ab}$ & $31.5 \mathrm{~d}$ & $43.5 \mathrm{c}$ & $5.0 \mathrm{a}$ & $35.0 \mathrm{c}$ & $39.5 \mathrm{~d}$ & $3.13 b$ & $21.5 \mathrm{e}$ \\
\hline \multirow{4}{*}{$45^{\circ} \mathrm{C}$} & 48 & $80.5 \mathrm{a}$ & $2.24 \mathrm{~cd}$ & $73.0 \mathrm{a}$ & $88.0 \mathrm{a}$ & $2.08 \mathrm{~cd}$ & $77.5 \mathrm{ab}$ & $86 b$ & $1.47 \mathrm{~d}$ & $79.5 \mathrm{~b}$ \\
\hline & 72 & $53.25 d$ & $3.07 \mathrm{bc}$ & $38.0 \mathrm{~d}$ & $60.0 \mathrm{~b}$ & $3.22 b$ & $38.5 \mathrm{c}$ & $42 d$ & $2.29 \mathrm{c}$ & $17.5 \mathrm{e}$ \\
\hline & 96 & $16.5 \mathrm{f}$ & $5.00 \mathrm{a}$ & $7.0 \mathrm{e}$ & $8.0 \mathrm{~d}$ & $5.46 \mathrm{a}$ & $3.0 \mathrm{~d}$ & $3.5 \mathrm{e}$ & 3.9 a & $0.0 \mathrm{f}$ \\
\hline & 120 & $0.5 \mathrm{~g}$ & $1.5 \mathrm{~d}$ & $0.0 \mathrm{e}$ & $0.0 \mathrm{~d}$ & $0.0 \mathrm{~d}$ & $0.0 \mathrm{~d}$ & $0.0 \mathrm{e}$ & $0.0 \mathrm{e}$ & $0.0 \mathrm{f}$ \\
\hline Control & 0 & $89.5 \mathrm{a}$ & $1.96 \mathrm{~d}$ & $79.0 \mathrm{a}$ & $89.0 \mathrm{a}$ & $1.80 \mathrm{c}$ & $82.5 \mathrm{a}$ & $94.0 \mathrm{a}$ & $1.58 \mathrm{~d}$ & $87.0 \mathrm{a}$ \\
\hline \multirow{2}{*}{ Temp. } & \multirow{2}{*}{$\begin{array}{l}\text { Time } \\
\text { (hour) }\end{array}$} & \multicolumn{3}{|c|}{ Montola 2000} & \multicolumn{3}{|c|}{ Linas } & \multicolumn{3}{|c|}{ Olas } \\
\hline & & GP & MGT & NSP & GP & MGT & NSP & GP & MGT & NSP \\
\hline \multirow{4}{*}{$43^{\circ} \mathrm{C}$} & 48 & $91.0 \mathrm{a}$ & $2.10 \mathrm{bc}$ & $86.0 \mathrm{a}$ & $82.5 \mathrm{a}$ & $2.36 \mathrm{~cd}$ & $71.0 \mathrm{a}$ & $87.0 \mathrm{~b}$ & $2.4 \mathrm{~cd}$ & $77.0 \mathrm{ab}$ \\
\hline & 72 & $79.0 \mathrm{~b}$ & $1.86 \mathrm{bc}$ & $67.5 \mathrm{~b}$ & $67.0 \mathrm{~b}$ & $2.61 \mathrm{~cd}$ & $54.5 \mathrm{~b}$ & $78.5 \mathrm{c}$ & $2.7 \mathrm{~cd}$ & $72.0 \mathrm{~b}$ \\
\hline & 96 & $79.0 \mathrm{~b}$ & $3.16 \mathrm{~b}$ & $72.5 \mathrm{~b}$ & $50.5 \mathrm{c}$ & $3.74 \mathrm{~b}$ & $45.0 \mathrm{c}$ & $47.0 \mathrm{e}$ & $4.7 \mathrm{~b}$ & $42.5 \mathrm{~d}$ \\
\hline & 120 & $36.0 \mathrm{~d}$ & $3.79 \mathrm{~b}$ & $26.0 \mathrm{c}$ & $19.0 \mathrm{e}$ & $6.02 \mathrm{a}$ & $9.5 \mathrm{e}$ & $15.5 \mathrm{~g}$ & $6.03 a$ & $12.5 \mathrm{f}$ \\
\hline \multirow{4}{*}{$45^{\circ} \mathrm{C}$} & 48 & $92.0 \mathrm{a}$ & $1.91 \mathrm{bc}$ & $81.5 \mathrm{a}$ & $69.0 \mathrm{~b}$ & $2.54 \mathrm{~cd}$ & $58.5 b$ & $67.5 \mathrm{~d}$ & $2.88 \mathrm{c}$ & $59.5 \mathrm{c}$ \\
\hline & 72 & $46.5 \mathrm{c}$ & $3.25 \mathrm{~b}$ & $27.5 \mathrm{c}$ & $41.0 \mathrm{~d}$ & $3.2 b c$ & $21.0 \mathrm{~d}$ & $33.0 \mathrm{f}$ & $4.14 b$ & $22.0 \mathrm{e}$ \\
\hline & 96 & $13.5 \mathrm{e}$ & $5.61 \mathrm{a}$ & $5.5 \mathrm{~d}$ & $4.5 \mathrm{f}$ & $5.45 \mathrm{a}$ & $1.0 \mathrm{f}$ & $5.5 \mathrm{~h}$ & $6.06 \mathrm{a}$ & $3.5 \mathrm{~g}$ \\
\hline & 120 & $0.5 \mathrm{f}$ & $1.5 \mathrm{c}$ & $0.0 \mathrm{~d}$ & $0.0 \mathrm{f}$ & $0.0 \mathrm{e}$ & $0.0 \mathrm{f}$ & $0.0 \mathrm{~h}$ & $0.0 \mathrm{e}$ & $0.0 \mathrm{~g}$ \\
\hline Control & 0 & $93.0 \mathrm{a}$ & $1.47 \mathrm{c}$ & $86.5 \mathrm{a}$ & $83.0 \mathrm{a}$ & $1.71 \mathrm{~d}$ & $71.0 \mathrm{a}$ & $93.0 \mathrm{a}$ & $1.86 \mathrm{~d}$ & $81.5 \mathrm{a}$ \\
\hline
\end{tabular}

$a, b, c$ Means followed by the same letter (s) are not significantly different at $p \leq 0.05$.

\section{Biochemical analysis in relation to seed deterioration}

Total carotene content of the seeds of the least and most aging genotypes decreased during the test compared to control. Carotene content of Bayer- 6 and Bayer- 12 decreased steadily until $96 \mathrm{~h}$ of aging, but increased at $120 \mathrm{~h}$ of aging (Table 3). In Linas and Olas, the decrease in carotene content during aging was not regular compared to control. Total carotene content in the Bayer- 6 and Bayer- 12 decreased by 47 and 32\%, respectively, after $120 \mathrm{~h}$ of aging, compared to control. In Linas and Olas, the decrease in carotene content was 37 and $23 \%$, respectively.

Biochemical changes in the seeds at the molecular level are related to seed degradation (Rejeendran et al., 2018). Seed aging causes production of ROS, enzyme inactivation, degradation of cell membranes and genetic changes. Seeds have non-enzymatic defense mechanisms to reduce the effect of ROS species. The non-enzymatic detoxifying compounds in the seeds are carotenes, vitamins and phenolic substances.

Carotenoids contribute to antioxidant systems to prevent production of free radicals, leading to membrane degradation and seed aging. In addition, carotenoids protect the seed oil against oxidation. Smolikova and Medvedev (2015) reported a 2.5 -fold increase in carotenoid level, after aging for six days at $40{ }^{\circ} \mathrm{C}$ in cabbage seeds. Carotene content gradually decreased in seeds aged in $100 \%$ relative humidity at $40{ }^{\circ} \mathrm{C}$, ROS level increased 2.5 times, and wheat seeds lost their germination ability completely (Galleschi et al., 2002). In this study, carotenoid contents in four genotypes decreased gradually after the AA, showing that the carotenoid levels in safflower seeds contribute to protect 
seeds from degradation and to prevent the loss of seed viability.

Xanthophylls are the oxygen carrying forms of carotenes, and significant decreases in the total amount of xanthophylls were also observed along with carotenes. The change in the total xanthophyll content of the least and most aging genotypes was different from the change in carotene content, and the xanthophyll content decreased at different rates in different aging times compared to the control. The total xanthophyll content of the genotypes decreased, but there was a burst in the total amounts of xanthophyll after $96 \mathrm{~h}$ or $120 \mathrm{~h}$ of aging. Bayer- 6 and Linas decreased by 49 and $53 \%$, respectively, compared to control after $96 \mathrm{~h}$ of aging. A correlation between xanthophyll content and aging in wheat seeds was reported: the determination of carotene and xanthophyll content can be effective in rapidly evaluating the aging of wheat seeds (Pinzino et al., 1999).

The total soluble phenolics content of the genotypes after $0 \mathrm{~h}$ was highest, phenolics content decreased in various amounts during AA, and it was the lowest at $120 \mathrm{~h}$. The phenolics content in Bayer-12, Linas and Olas decreased regularly until $72 \mathrm{~h}$, but increased after $96 \mathrm{~h}$. Reduction of phenolics content in Bayer- 6 during the AA was not regular. After $120 \mathrm{~h}$ of aging, the highest reduction in the total phenolics content was observed in Bayer-12 (33\%), and the lowest in the Bayer- 6 (12\%) (Table 3). The total flavonoid content of the genotypes decreased regularly during the AA. The total flavonoid content of the Bayer- 6 and Bayer- 12 genotypes decreased by $8 \%$ and $14 \%$, respectively, after $120 \mathrm{~h}$ of aging, compared to the control. In Linas and Olas, the decrease in flavonoid content was $12 \%$ and $11 \%$, respectively (Table 3 ).

Phenolics and flavonoids prevent lipid peroxidation by giving electrons to ROS species, which are formed due to

Table 3. Effect of accelerated aging on carotene, xanthophyll, total phenolic, total flavonoid, total soluble protein and tocopherol content in safflower seeds.

\begin{tabular}{|c|c|c|c|c|c|c|c|}
\hline Genotype & $\begin{array}{l}\text { Ageing } \\
\text { time (h) }\end{array}$ & $\begin{array}{l}\text { Carotene } \\
\left(\mu \mathrm{g} \cdot \mathrm{g}^{-1}\right)\end{array}$ & $\begin{array}{l}\text { Xanthophyll } \\
\left(\mu \mathrm{g} \cdot \mathrm{g}^{-1}\right)\end{array}$ & $\begin{array}{c}\text { Total soluble } \\
\text { phenolics } \\
\left(\mathrm{mg} \cdot \mathrm{g}^{-1}\right)\end{array}$ & $\begin{array}{l}\text { Total flavonoid } \\
\quad\left(\mathrm{mg}^{\left.-\mathrm{g}^{-1}\right)}\right.\end{array}$ & $\begin{array}{l}\text { Total soluble } \\
\text { protein }\left(\mathrm{mg}^{-\mathrm{g}^{-1}}\right)\end{array}$ & $\begin{array}{l}\text { Tocopherol } \\
\left(\mathrm{mg}^{\left.-\mathrm{g}^{-1}\right)}\right.\end{array}$ \\
\hline \multirow{5}{*}{ Bayer-6 } & 0 (Control) & $7.02 \mathrm{a}$ & $6.65 a$ & 0.807 a & $0.734 a$ & $5.20 \mathrm{a}$ & $0.654 a b$ \\
\hline & 48 & $3.69 \mathrm{bc}$ & $3.72 \mathrm{c}$ & $0.653 c$ & $0.736 a b$ & $5.03 \mathrm{a}$ & $0.636 \mathrm{~b}$ \\
\hline & 72 & $3.57 \mathrm{~b}$ & $3.44 \mathrm{~d}$ & $0.724 \mathrm{~b}$ & $0.739 a b$ & $4.73 \mathrm{~b}$ & $0.625 \mathrm{~b}$ \\
\hline & 96 & $3.49 c$ & $3.39 \mathrm{~d}$ & $0.611 \mathrm{~d}$ & $0.718 \mathrm{~b}$ & $4.06 \mathrm{c}$ & $0.683 \mathrm{a}$ \\
\hline & 120 & $3.72 \mathrm{~b}$ & $4.14 \mathrm{~b}$ & $0.712 \mathrm{~b}$ & $0.680 \mathrm{c}$ & $3.41 \mathrm{~d}$ & $0.688 \mathrm{a}$ \\
\hline \multirow{5}{*}{ Bayer-12 } & 0 (Control) & $6.19 \mathrm{a}$ & $5.49 \mathrm{a}$ & $0.865 \mathrm{a}$ & $0.782 \mathrm{a}$ & $4.89 a$ & $0.581 \mathrm{ba}$ \\
\hline & 48 & $4.24 \mathrm{~b}$ & $4.22 \mathrm{~b}$ & $0.606 \mathrm{~b}$ & $0.703 \mathrm{~b}$ & $4.19 \mathrm{~b}$ & $0.544 \mathrm{bc}$ \\
\hline & 72 & $3.90 \mathrm{c}$ & $3.70 \mathrm{~b}$ & $0.547 \mathrm{~b}$ & $0.697 \mathrm{~b}$ & $3.99 \mathrm{c}$ & $0.538 c$ \\
\hline & 96 & $3.84 \mathrm{~cd}$ & $3.97 \mathrm{c}$ & $0.588 \mathrm{~b}$ & $0.680 \mathrm{bc}$ & $3.94 \mathrm{c}$ & $0.613 a$ \\
\hline & 120 & $4.22 \mathrm{~b}$ & $3.69 \mathrm{~b}$ & $0.576 \mathrm{~b}$ & $0.668 \mathrm{c}$ & $3.81 \mathrm{c}$ & $0.619 \mathrm{a}$ \\
\hline \multirow{5}{*}{ Linas } & 0 (Control) & $7.32 \mathrm{a}$ & $6.69 a$ & $0.736 \mathrm{a}$ & $0.739 a$ & $4.44 \mathrm{a}$ & $0.694 \mathrm{a}$ \\
\hline & 48 & $4.80 \mathrm{c}$ & $3.62 \mathrm{~b}$ & $0.626 c$ & $0.711 \mathrm{~b}$ & $4.21 \mathrm{~b}$ & $0.688 \mathrm{a}$ \\
\hline & 72 & $4.55 \mathrm{~d}$ & $3.52 \mathrm{~b}$ & $0.591 \mathrm{c}$ & $0.712 \mathrm{~b}$ & $4.07 \mathrm{~b}$ & $0.685 a$ \\
\hline & 96 & $5.10 \mathrm{~b}$ & $3.12 \mathrm{c}$ & $0.686 \mathrm{~b}$ & $0.699 \mathrm{bc}$ & $4.03 \mathrm{~b}$ & $0.678 a b$ \\
\hline & 120 & $4.64 \mathrm{~d}$ & $3.54 \mathrm{~b}$ & $0.526 \mathrm{~d}$ & $0.647 c$ & $3.83 \mathrm{c}$ & $0.653 \mathrm{~b}$ \\
\hline \multirow{5}{*}{ Olas } & 0 (Control) & $6.24 \mathrm{a}$ & $5.35 a$ & $0.855 \mathrm{a}$ & $0.728 a$ & $4.58 a$ & $0.675 \mathrm{a}$ \\
\hline & 48 & $4.29 \mathrm{c}$ & $3.39 \mathrm{~d}$ & $0.754 \mathrm{~b}$ & $0.724 a$ & $4.53 \mathrm{a}$ & $0.587 \mathrm{~b}$ \\
\hline & 72 & $4.67 \mathrm{~b}$ & $3.72 \mathrm{c}$ & $0.561 \mathrm{~d}$ & $0.714 \mathrm{a}$ & $4.45 \mathrm{ab}$ & $0.584 b c$ \\
\hline & 96 & $4.40 \mathrm{c}$ & $3.89 \mathrm{c}$ & $0.668 \mathrm{c}$ & $0.657 \mathrm{~b}$ & $4.39 \mathrm{~b}$ & $0.545 \mathrm{c}$ \\
\hline & 120 & $4.77 \mathrm{~b}$ & $4.25 \mathrm{~b}$ & $0.579 \mathrm{~d}$ & $0.647 \mathrm{~b}$ & $3.90 \mathrm{c}$ & $0.528 \mathrm{c}$ \\
\hline
\end{tabular}

$a, b, c$ Means followed by the same letter (s) are not significantly different at $p \leq 0.05$. 
aging, and found in testa, endosperm and embryo. There is a high correlation between total phenolic content and seed viability, and phenolic substances play an important role in preventing seed aging processes (Debeaujon et al., 2000; Pukacka and Ratajczak, 2007). Total phenolic content of the clover seeds aged 42 years under natural conditions was greatly reduced compared to the control seeds (Cakmak et al., 2010). Storing Fagus sylvatica L. seeds for 2, 5, 7 and 10 years at $-10{ }^{\circ} \mathrm{C}$ reduced the total phenolics content of cotyledon and embryonic axes, as the storage time increased (Pukacka and Ratajczak, 2007).

Total soluble protein content decreased regularly during the AA (Table 3). Reduction in soluble protein content started after $48 \mathrm{~h}$ in Bayer-12 and Linas, and after $72 \mathrm{~h}$ in Bayer- 6 and Olas. After $120 \mathrm{~h}$, the highest decrease in protein content was in Bayer-6 (34\%), while the lowest decrease was in Linas (14\%).

High protein content in the seeds helps to support vigor and viability (Rejeendran et al., 2018). The oxidation in proteins contribute to the decrease in the seeds' germination rate (Sano et al., 2016). Decrease in protein content is considered as a common indicator and index of oxidative stress. Moori and Eisvand (2017) reported that seed degradation after AA is an indicator of the decrease in enzymatic activity and in total soluble protein content in wheat. The total soluble protein content decrease dependend on storage period in Jatropha curcas seeds (Silva et al., 2018). Safflower seeds contained 4.44-5.20 mg.g ${ }^{-1}$ protein. Bayer-6 and Bayer-12 had higher soluble protein content. In the present study, the total soluble protein content in all genotypes decreased regularly during the $A A$, but reduction in soluble protein content was higher in Bayer- 6 and Bayer- 12 .

Changes in the total tocopherol content between the genotypes were different throughout the test. The tocopherol content of Bayer- 6 and Bayer- 12 decreased until $72 \mathrm{~h}$ of aging, but increased after $96 \mathrm{~h}$ of aging. The tocopherol content was higher after $120 \mathrm{~h}$, compared to $0 \mathrm{~h}$. On the other hand, Linas and Olas did not show an increase in tocopherol content, and its level dropped untill $120 \mathrm{~h}$ (Table 3).

One of the most important antioxidants stored in seeds is tocopherol. Tocopherols are considered the most important non-enzymatic inhibitors of lipid peroxidation. The main function of tocopherols in seeds is to remove ROS resulting from lipid peroxidation during aging, storage, germination and seedling development (Sattler et al., 2004). Decrease in germination was related to the decrease in the total tocopherol content in the seeds of Pinus sylvestris L. (Tammela et al., 2005), Fagus sylvatica L. (Pukacka and Ratajczak, 2007), Suaeda maritima L. (Seal et al., 2010) and sunflower (Draganić et al., 2011). Arabidopsis mutants deficient in tocopherol synthesis showed decreased GP when exposed for $72 \mathrm{~h}$ at $40{ }^{\circ} \mathrm{C}$ (Sattler et al., 2004). In addition, the tocopherol deficiency caused lipid peroxidation in mutant lines during seed aging. These studies confirmed that tocopherols prolonged seed life. In the present study, the total tocopherol content in the most aging genotypes decreased dramatically. The total tocopherol content increased after aging for 96 and $120 \mathrm{~h}$ in the least aging genotypes. It was observed that tocopherol content in safflower seeds prolongs seed life during the AA.

While the total soluble sugars content decreased, reducing sugars content increased during the AA period for all genotypes. Changes in total soluble sugar content between the genotypes differed depending on aging times. Just as the changes in tocopherol content, the soluble sugar content in Bayer- 6 and Bayer-12 decreased steadily until $72 \mathrm{~h}$ of aging, but increased after $96 \mathrm{~h}$ of aging. Linas and Olas also showed decrease in the soluble sugars content, but it was not regular with AA time (Table 4). The reducing sugars content in Bayer-6, Bayer-12, Linas and Olas increased by 63\%, $47 \%, 77 \%$ and $59 \%$, respectively, after $120 \mathrm{~h}$ of aging (Table 4 ).

Sugars are usually stored as starch. In the seeds, the soluble sugars are used for respiration, followed by lipids or starches. During the storage and AA, the starch content of the seeds decreases at different rates, while the amounts of monosaccharides and disaccharides increase (Murthy et al., 2003). Monosaccharides are combined with aldehyde, ketone, and amino group of proteins, and are converted into reducing sugars. Reducing sugars can cause damage to DNA, RNA and changes the structure of proteins, reducing the viability (McDonald, 1999; Sun and Leopold, 1995). Reduction in the total soluble sugar content and increase in the reducing sugars content was reported for different species during the aging, such as mung bean (Murthy et al., 2003), canola (Wang et al., 2018) and Brassica campestris (Jiang et al., 2018). 
Table 4. Effect of AA on total reducing sugars, total soluble sugars, oil content, total free acids, and malondialdehyde content in safflower seeds.

\begin{tabular}{|c|c|c|c|c|c|c|}
\hline Genotype & $\begin{array}{l}\text { Ageing time } \\
\text { (h) }\end{array}$ & $\begin{array}{l}\text { Total reducing sugars } \\
\left(\mathrm{mg}^{\left.-\mathrm{g}^{-1}\right)}\right.\end{array}$ & $\begin{array}{l}\text { Total soluble } \\
\text { sugars }\left(\mathrm{mg}^{\left.-\mathrm{g}^{-1}\right)}\right.\end{array}$ & $\begin{array}{l}\text { Oil content } \\
(\%)\end{array}$ & $\begin{array}{l}\text { Total free fatty } \\
\text { Acids }\left(\mathrm{mg}^{-1}\right)\end{array}$ & $\begin{array}{l}\text { Malondialdehyde } \\
\quad\left(\mathrm{nmol}^{\left.-\mathrm{g}^{-1}\right)}\right.\end{array}$ \\
\hline \multirow{5}{*}{ Bayer-6 } & 0 (Control) & $0.30 \mathrm{c}$ & $1.16 \mathrm{a}$ & $30.80 \mathrm{a}$ & $0.68 c$ & $31.52 \mathrm{a}$ \\
\hline & 48 & $0.40 \mathrm{~b}$ & $0.62 b$ & $30.53 a$ & $0.85 \mathrm{~b}$ & $28.73 \mathrm{~b}$ \\
\hline & 72 & $0.41 b$ & $0.46 \mathrm{de}$ & $29.72 a b$ & $0.98 \mathrm{a}$ & $19.07 \mathrm{c}$ \\
\hline & 96 & $0.48 \mathrm{a}$ & $0.54 \mathrm{c}$ & $29.27 a b$ & $0.68 c$ & $17.83 \mathrm{c}$ \\
\hline & 120 & $0.49 \mathrm{a}$ & $0.50 \mathrm{~d}$ & $28.15 b$ & $0.69 c$ & $14.36 \mathrm{~d}$ \\
\hline \multirow{5}{*}{ Bayer-12 } & 0 (Control) & $0.38 \mathrm{c}$ & $1.12 \mathrm{a}$ & $32.86 \mathrm{a}$ & $0.49 \mathrm{~d}$ & $41.59 \mathrm{a}$ \\
\hline & 48 & $0.39 c$ & $0.55 \mathrm{~b}$ & $32.80 a b$ & $0.78 \mathrm{~b}$ & $39.52 \mathrm{a}$ \\
\hline & 72 & $0.48 \mathrm{~b}$ & $0.49 c$ & $31.70 \mathrm{~b}$ & $1.11 \mathrm{a}$ & $37.07 \mathrm{~b}$ \\
\hline & 96 & $0.55 a$ & $0.55 \mathrm{~b}$ & $31.69 \mathrm{~b}$ & $0.69 c$ & $31.77 \mathrm{c}$ \\
\hline & 120 & $0.56 \mathrm{a}$ & $0.52 b c$ & $31.25 \mathrm{~b}$ & $0.79 \mathrm{~b}$ & $31.65 \mathrm{c}$ \\
\hline \multirow{5}{*}{ Linas } & 0 (Control) & $0.34 \mathrm{~d}$ & $1.23 \mathrm{a}$ & $35.31 \mathrm{ab}$ & $0.50 \mathrm{~d}$ & $35.50 \mathrm{a}$ \\
\hline & 48 & $0.44 \mathrm{c}$ & $0.47 c$ & $35.02 a b$ & $0.66 c$ & $26.40 \mathrm{~b}$ \\
\hline & 72 & $0.48 \mathrm{~b}$ & $0.61 b$ & $34.48 b$ & $0.89 a$ & $24.34 \mathrm{bc}$ \\
\hline & 96 & $0.50 \mathrm{~b}$ & $0.34 \mathrm{~d}$ & $34.21 b c$ & $0.67 c$ & $23.30 \mathrm{c}$ \\
\hline & 120 & $0.60 \mathrm{a}$ & $0.14 \mathrm{e}$ & $32.72 \mathrm{c}$ & $0.77 \mathrm{~b}$ & $17.93 \mathrm{~d}$ \\
\hline \multirow{5}{*}{ Olas } & 0 (Control) & $0.34 \mathrm{~d}$ & $1.38 \mathrm{a}$ & $36.37 \mathrm{a}$ & $0.52 \mathrm{~d}$ & $37.85 \mathrm{a}$ \\
\hline & 48 & $0.39 c$ & $0.49 \mathrm{bc}$ & $36.18 \mathrm{a}$ & $0.94 \mathrm{a}$ & $28.67 b$ \\
\hline & 72 & $0.46 \mathrm{~b}$ & $0.54 \mathrm{~b}$ & $35.63 \mathrm{a}$ & $0.83 \mathrm{~b}$ & $27.25 b c$ \\
\hline & 96 & $0.48 \mathrm{~b}$ & $0.51 \mathrm{~b}$ & $34.44 \mathrm{~b}$ & $0.59 \mathrm{~cd}$ & $25.70 \mathrm{c}$ \\
\hline & 120 & $0.54 \mathrm{a}$ & $0.45 \mathrm{c}$ & $33.94 \mathrm{~b}$ & $0.65 c$ & $22.86 \mathrm{~d}$ \\
\hline
\end{tabular}

a,b,c Means followed by the same letter (s) are not significantly different at $p \leq 0.05$.

The oil content of the genotypes decreased regularly during the AA (Table 4). The oil content in Bayer- 6 and Bayer- 12 decreased by 9 and 5\%, respectively, compared to the control after $120 \mathrm{~h}$ of aging. The decrease in oil content was $7 \%$ in both Linas and Olas. The total free fatty acids content was the lowest at the beginning of the experiment for all genotypes, and free fatty acids in the seeds of the least and most aging genotypes increased at different rates. Free fatty acids contents in Bayer-6, Bayer-12, and Linas increased until $72 \mathrm{~h}$ of aging, but decreased after $96 \mathrm{~h}$ of aging. Olas had the highest free fatty acids content at $48 \mathrm{~h}$ aging (Table 4). Oilferous seeds age very rapidly due to their high content of polyunsaturated fatty acids. The oil content in the seeds had a significant effect on the seeds' storage life, and it was significantly affected by the storage conditions. It was reported that oil content in the seeds of Jatropha curcas (Lozano-Isla et al., 2018), Arabidopsis thaliana (Oenel et al., 2017) and sunflower (Balešević-Tubić et al., 2007) decreased during storage and AA.

Free fatty acids are formed as a result of the triacylglycerols degradation in the seeds. Free fatty acids accumulation in the cytoplasm reduces $\mathrm{pH}$ of the oil and conversion of free fatty acids to different molecules, and the permeability of the membranes increase (Tammela et al., 2005). Free fatty acids are formed during the storage of seeds and AA, and the oil quality and germination rate decreases depending on the amount of free fatty acids formed (Balešević-Tubić et al., 2007). The total free fatty acids content in the seeds of Jatropha curcas (Akowuah et al., 2012), Arabidopsis (Oenel et al., 2017), sesame (Kavitha et al., 2017) and cotton (Nik et al., 2011) increased as the aging or storage time increased.

Studies on MDA level after aging or during storage showed that MDA accumulation varies in plant species. It was suggested that lipid peroxidation in oilseed plants is an important factor in seed degradation, and MDA level could be 
used as an indicator of lipid peroxidation in seeds during aging. MDA amount increased in plant species such as: wheat (Moori and Eisvand., 2017), oat (Xia et al., 2015), canola (Yin et al., 2015), soybean (Sharma et al., 2013), Arabidopsis (Devaiah et al., 2007), and sunflower (Kibinza et al., 2006), during aging. Despite these assumptions, Lehner et al. (2008) reported that the amount of MDA decreased after AA in two wheat varieties, and MDA levels in Jatropha curcas decreased after storage (Silva et al., 2018). MDA levels after AA decreased in four different species of Brassicaceae, and lipid peroxidation was not the main cause of seed degradation (Mira et al., 2011). The MDA content was higher at $0 \mathrm{~h}$ for all genotypes than the AA applied seeds. The MDA content of the genotypes after AA decreased regularly with increased aging time. The MDA content in Bayer-6, Bayer-12, Linas and Olas decreased by 54\%, 24\%, 50\% and $40 \%$, respectively, after $120 \mathrm{~h}$ of aging, indicating that lipid peroxidation was not the main cause of seed aging in safflower during the AA (Table 4).

\section{CONCLUSIONS}

Safflower genotypes showed different responses to $A A$, and the $A A$ at $43{ }^{\circ} \mathrm{C}$ was suitable to asses effects of aging in safflower. Carotene, xanthophyll, soluble phenolics, flavonoid, soluble protein, soluble sugars, oil contents and MDA levels decreased, and reducing sugars and total free fatty acids increased varying amounts among the genotypes during the AA. The total tocopherol content increased in aging resistant genotypes and decreased in aging sensitive genotypes. The lipid peroxidation as indicated by the MDA levels in safflower seeds was not the main cause of seed degradation during the AA.

\section{REFERENCES}

AKOWUAH, J.O.; ADDO, A.; KEMAUSUOR, F. Influence of storage duration of Jatropha curcas seed on oil yield and free fatty acid content. ARPN Journal of Agricultural and Biological Science, v.7, n.1, p.41-45, 2012. http://www.arpnjournals.com/jabs/research_ papers/rp_2012/jabs_0112_353.pdf

AOAC. Association of Official Analytical Chemists. Official methods of analysis. Washington DC, 1984. 800p.

BACKER, H.; FRANK, O.; ANGELIS, B.; FEINGOLD, S. Plasma tocopherol in man at various times after ingesting free or acetylated tocopherol. Nutrition Reports International, v.21, n.4, p.531-536, 1980.

BALEŠEVIĆ-TUBIĆ, S.; TATIĆ, M.; MILADINOVIĆ, J.; PUCAREVIĆ, M. Changes of fatty acids content and vigour of sunflower seed during natural aging. Helia, v.30, n.47, p.61-68, 2007. http://www.doiserbia.nb.rs/img/doi/1018-1806/2007/1018-18060747061b.pdf

BAYDAR, H.; ÜLGER, S. Correlations between changes in the amount of endogenous phytohormones and flowering in the safflower (Carthamus tinctorius L.). Turkish Journal of Biology, v.22, n.4, p.421-425, 1998. http://journals.tubitak.gov.tr/biology/issues/biy98-22-4/biy-22-4-6-97067.pdf

BERGER, S.; WEICHERT, H.; PORZEL, A.; WASTERNACK, C.; KÜHN, H.; FEUSSNER, I. Enzymatic and non-enzymatic lipid peroxidation in leaf development. Biochimica et Biophysica Acta, v.1533, n.3, p.266-276, 2001. https://www.sciencedirect.com/science/article/ pii/S1388198101001615

CAKMAK, T.; ATICI, O.; AGAR, G.; SUNAR, S. Natural aging-related biochemical changes in alfalfa (Medicago sativa L.) seeds stored for 42 years. International Research Journal of Plant Science, v.1, n.1, p.1-6, 2010. http://earsiv.ebyu.edu.tr/xmlui/bitstream/ handle/20.500.12432/1581/Natural\%20aging-related\%20biochemical\%20changes\%20in\%20alfalfa\%20\%28Medicago\%20 Sativa\%20L.\%29\%20seeds\%20stored\%20for\%2042\%20years.pdf?sequence=1\&isAllowed=y

DEBEAUJON, I.; LÉON-KLOOSTERZIEL, K.M.; KOORNNEEF, M. Influence of the testa on seed dormancy, germination, and longevity in Arabidopsis. Plant Physiology, v.122, n.2, p.403-413, 2000. http://www.plantphysiol.org/content/plantphysiol/122/2/403.full.pdf

DEMIR, M. Conformity of vigor tests to determine the seed quality of safflower (Carthamus tinctorius L.) cultivars. Australian Journal of Crop Sciences, v.8, n.3, p.455-459, 2014. https://search.informit.com.au/documentSummary;dn=211438141472661;res=IELHSS

DEVAIAH, S.P.; PAN, X.; HONG, Y.; ROTH, M.; WELTI, R.; WANG, X. Enhancing seed quality and viability by suppressing phospholipase D in Arabidopsis. The Plant Journal, v.50, n.6, p.950-957, 2007. https://onlinelibrary.wiley.com/doi/pdf/10.1111/j.1365313X.2007.03103.x 
DIAS, M.A.N.; MONDO, V.H.V.; CICERO, S.M.; GONÇALVES, N.R.; SILVA, C.A.T. Vigor tests association as an alternative for precise and efficient assessment of maize seed quality. Revista Caatinga, v.28, n.3, p.93-99, 2015. http://www.scielo.br/scielo.php?pid=S198321252015000300093\&script=sci_arttext

DRAGANIĆ, I.; LEKIĆ, S.; BRANKOVIĆ, T.; TODOROVIĆ, G. Fatty acids and tocopherol content in sunflower seeds affected by accelerated againg and priming with antioksidant solutions. Turkish Journal of Field Crops, v.16, n.2, p.100-104, 2011. https:// dergipark.org.tr/download/article-file/158708

DUBOIS, M.; GILLES, K.A.; HAMILTON, J.K.; REBERS, P.A.; SMITH, F. Colorimetric method for determination of sugars and related substances. Analytical Chemistry, v.28, n.3, p.350-356, 1956. https://pubs.acs.org/doi/abs/10.1021/ac60111a017

FAO. Food and Agriculture Organization of the United Nations. Statistical data for safflower agriculture. 2019. http://www.fao.org/ faostat/en/\#data/QC

GALLESCHI, L.; CAPOCCHI, A.; GHIRINGHELLI, S.; SAVIOZZI, F.; CALUCCI, L.; PINZINO, C.; ZANDOMENEGHI, M. Antioxidants, free radicals, storage proteins, and proteolytic activities in wheat (Triticum durum) seeds during accelerated aging. Journal of Agricultural and Food Chemistry, v.50, n.19, p.5450-5457, 2002. https://pubs.acs.org/doi/abs/10.1021/jf0201430

GHAHFAROKHI, M.G.; GHASEMI, E.; SAEIDI, M.; KAZAFI, Z.H. The effect of accelerated aging on germination characteristics, seed reserve utilization and malondialdehyde content of two wheat cultivars. Journal of Stress Physiology and Biochemistry, v.10, n.2, p.1523, 2014. https://cyberleninka.ru/article/n/the-effect-of-accelerated-aging-on-germination-characteristics-seed-reserve-utilizationand-malondialdehyde-content-of-two-wheat/viewer

HARRINGTON, J.F. Seed storage and longevity. $3^{\text {rd }}$ ed. New York: Academic Press, 1972. 434p.

HARTREE, E.F. Determination of protein: a modification of the Lowry method that gives a linear photometric response. Analytical Biochemistry, v.48, n.2, p.422-427, 1972. https://www.sciencedirect.com/science/article/abs/pii/0003269772900942?via\%3Dihub

ISTA. International Seed Testing Association. International rules for seed testing. Bassersdorf, 2009. 355p.

JIANG, F.L.; BO, L.P.;XU, J.J.; WU, Z. Changes in respiration and structure of non-heading Chinese cabbage seeds during gradual artificial aging. Scientia Horticulturae, v.238, p.14-22, 2018. https://www.sciencedirect.com/science/article/pii/S0304423818302607

KAVITHA, S.; MENAKA, C.; ANANTHI, M. Deterioration in sesame (Sesamum indicum L.) seeds under natural and accelerated ageing. International Journal of Chemical Studies, v.5, n.4, p.1141-1146, 2017. http://www.chemijournal.com/archives/2017/vol5issue4/ PartQ/5-4-127-752.pdf

KIBINZA, S.; VINEL, D.; CÔME, D.; BAILLY, C.; CORBINEAU, F. Sunflower seed deterioration as related to moisture content during ageing, energy metabolism and active oxygen species scavenging. Physiologia Plantarum, v.128, p.496-506, 2006. https:// onlinelibrary.wiley.com/doi/pdf/10.1111/j.1399-3054.2006.00771.x

LEHNER, A.; MAMADOU, N.; POELS, P.; CÔME, D.; BAILLY, C.; CORBINEAU, F. Changes in soluble carbohydrates, lipid peroxidation and antioxidant enzyme activities in the embryo during ageing in wheat grains. Journal of Cereal Science, v.47, n.3, p.555-565, 2008. https://www.sciencedirect.com/science/article/pii/S0733521007001312

LOWRY, R.R.; TINSLEY, I.J. Rapid colorimetric determination of free fatty acids. Journal of the American Oil Chemists' Society, v.53, p.470-472, 1976. https://link.springer.com/article/10.1007/BF02636814

LOZANO-ISLA, F.; CAMPOS, M.L.O.; ENDRES, L.; BEZERRA-NETO, E.; POMPELLI, M.F. Effects of seed storage time and salt stress on the germination of Jatropha curcas L. Industrial Crops and Products, v.118, p.214-224, 2018. https://www.sciencedirect.com/ science/article/abs/pii/S0926669018302759

MCDONALD, M.B. Seed deterioration: physiology, repair and assessment. Seed Science and Technology, v.27, n.1, p.177-237, 1999. https://www.tib.eu/en/search/id/BLSE\%3ARN065546565/Seed-deterioration-physiology-repair-and-assessment/

MCDONALD, M.B.; KWONG, F.Y. Flower seeds: biology and technology. Wallingford: Centre for Agriculture and Biosciences International Publishing, 2005. 372p.

MIRA, S.; ESTRELLES, E.; GONZÁLEZ-BENITO, M.E.; CORBINEAU, F. Biochemical changes induced in seeds of Brassicaceae wild species during ageing. Acta Physiologiae Plantarum, v.33, n.5, p.1803-1809, 2011. https://link.springer.com/article/10.1007/ s11738-011-0719-7 
MOORI, S.; EISVAND, H.R. Plant growth regulators and ascorbic acid effects on physiological quality of wheat seedlings obtained from deteriorated seeds. Pakistan Journal of Botany, v.49, n.5, p.1811-1819, 2017. https://www.pakbs.org/pjbot/papers/1507286193.pdf

MURTHY, U.M.N.; KUMAR, P.P.; SUN, W.Q. Mechanisms of seed ageing under different storage conditions for Vigna radiata (L.) Wilczek: lipid peroxidation, sugar hydrolysis, Maillard reactions and their relationship to glass state transition. Journal of Experimental Botany, v.54, n.384, p.1057-1067, 2003. https://academic.oup.com/jxb/article/54/384/1057/631142

NIK, S.M.; TILEBENI, H.G.; JAE, G.; SADEGHI, M.A.; SEDIGHI, E. Free fatty acid and electrical conductivity changes in cotton seed (Gossypium hirsutum) under seed deteriorating conditions. International Journal of Agricultural Science, v.1, n.2, p.62-66, 2011.

OENEL, A.; FEKETE, A.; KRISCHKE, M.; FAUL, S.C.; GRESSER, G.; HAVAUX, M.; MUELLER, M.J.; BERGER, S. Enzymatic and non-enzymatic mechanisms contribute to lipid oxidation during seed aging. Plant and Cell Physiology, v.58, n.5, p.925-933, 2017. https://academic. oup.com/pcp/article/58/5/925/3075305

PINZINO, C.; CAPOCCHI, A.; GALLESCHI, L.; SAVIOZZI, F.; NANNI, B.; ZANDOMENEGHI, M. Aging, free radicals, and antioxidants in wheat seeds. Journal of Agricultural and Food Chemistry, v.47, n.4, p.1333-1339, 1999. https://pubs.acs.org/doi/abs/10.1021/ jf980876d

PRIESTLEY, D.A. Seed aging. Ithaca: Cornell University Press, 1986. 304p.

PUKACKA, S.; RATAJCZAK, E. Age-related biochemical changes during storage of beech (Fagus sylvatica L.) seeds. Seed Science Research, v.17, n.1, p.45-53, 2007. https://www.cambridge.org/core/journals/seed-science-research/article/agerelatedbiochemical-changes-during-storage-of-beech-fagus-sylvatica-l-seeds/CF70FAADCBB484EC9532E5677C0E5D1E

REJEENDRAN, H.V.; LAKSHMI, S.; AMBIKA, S. Changes of enzymes activities in botanical treated aged seed of soybean (Glycine $\max$ (L.) Merrill) cv. $\mathrm{CO}_{3}$ seeds. Legume Research, v.41, p.73-78, 2018. https://arccjournals.com/journal/legume-research-aninternational-journal/LR-3589

SAKANAKA, S.; TACHIBANA, Y.; OKADA, Y. Preparation and antioxidant properties of extracts of Japanese persimmon leaf tea (kakinohacha). Food Chemistry, v.89, n.4, p.569-575, 2005. https://www.sciencedirect.com/science/article/pii/S0308814604002535

SANO, N.; RAJJOU, L.; NORTH, H.M.; DEBEAUJON, I.; MARION-POLL, A.; SEO. M. Staying alive: molecular aspects of seed longevity. Plant and Cell Physiology, v.57, n.4, p.660-674, 2016. https://academic.oup.com/pcp/article/57/4/660/2460931

SAS INSTITUTE. The complete guide to the SAS output delivery system. Version 8. SAS Institute, 1999.

SATTLER, S.E.; GILLILAND, L.U.; MAGALLANES-LUNDBACK, M.; POLLARD, M.; DELLAPENNA, D. Vitamin E is essential for seed longevity and for preventing lipid peroxidation during germination. The Plant Cell, v.16, p.1419-1432, 2004. http://www.plantcell. org/content/plantcell/16/6/1419.full.pdf

SEAL, C.E.; ZAMMIT, R.; SCOTT, P.; FLOWERS, T.J.; KRANNER, I. Glutathione half-cell reduction potential and $\alpha$-tocopherol as viability markers during the prolonged storage of Suaeda maritima seeds. Seed Science Research, v.20, n.1, p.47-53, 2010. https://www. cambridge.org/core/journals/seed-science-research/article/glutathione-halfcell-reduction-potential-and-tocopherol-as-viabilitymarkers-during-the-prolonged-storage-of-suaeda-maritima-seeds/D91DB81E7B1A9A80A815876307FC869F

SHARMA, S.; KAUR, A.; BANSAL, A.; GILL, B.S. Positional effects on soybean seed composition during storage. Journal of Food Science and Technology, v.50, p.353-359, 2013. https://link.springer.com/article/10.1007/s13197-011-0341-0

SILVA, L.J.; DIAS, D.C.F.S.; SEKITA, M.C.; FINGER, F.L. Lipid peroxidation and antioxidant enzymes of Jatropha curcas L. seeds stored at different maturity stages. Acta Scientiarum Agronomy, v.40, 2018. http://www.scielo.br/scielo.php?pid=S1807$86212018000100603 \&$ script=sci_arttext

SMOLIKOVA, G.N.; MEDVEDEV, S.S. Seed carotenoids: synthesis, diversity, and functions. Russian Journal of Plant Physiology, v.62, p.1-13, 2015. https://link.springer.com/article/10.1134/S1021443715010136

SOMOGYI, M. Notes on sugar determination. The Journal of Biological Chemistry, v.195, p.19-23, 1952. https://www.jbc.org/ content/195/1/19.full.pdf

SUN, W.Q.; LEOPOLD, A.C. The Maillard reaction and oxidative stress during ageing of soybean seeds. Physiologia Plantarum, v.94, n.1, p.94-104, 1995. https://onlinelibrary.wiley.com/doi/abs/10.1111/j.1399-3054.1995.tb00789.x 
TAMMELA, P.; SALO-VÄÄNÄNEN, P.; LAAKSO, I.; HOPIA, A.; VUORELA, H.; NYGREN, M. Tocopherols, tocotrienols and fatty acids as indicators of natural ageing in Pinus sylvestris seeds. Scandinavian Journal of Forest Research, v.20, n.5, p.378-384, 2005. https:// www.tandfonline.com/doi/full/10.1080/02827580500292063

TONGUÇ, M.; ELKOYUNU, R.; ERBAŞ, S.; KARAKURT, Y. Changes in seed reserve composition during germination and initial seedling development of safflower (Carthamus tinctorius L.). Turkish Journal of Biology, v.36, p.107-112, 2012. http://journals.tubitak.gov. tr/biology/issues/biy-12-36-1/biy-36-1-13-1012-164.pdf

USHA, T.N.; DADLANI, M. Evaluation of seed vigour in soybean (Glycine max). Legume Research, v.38, p.308-312, 2015. https:// arccjournals.com/journal/legume-research-an-international-journal/LR-2933

WANG, T.; HOU, L.; JIAN, H.; DI, F.; LI, J.; LIU, L. Combined QTL mapping, physiological and transcriptomic analyses to identify candidate genes involved in Brassica napus seed aging. Molecular Genetics and Genomics, v.293, p.1421-1435, 2018. https://link. springer.com/article/10.1007/s00438-018-1468-8

XIA, F.; CHEN, L.; SUN, Y.; MAO, P. Relationships between ultrastructure of embryo cells and biochemical variations during ageing of oat (Avena sativa L.) seeds with different moisture content. Acta Physiologiae Plantarum, v.37, n.89, p.1-11, 2015. https://link. springer.com/article/10.1007/s11738-015-1825-8

YIN, X.; HE, D.; GUPTA, R.; YANG, P. Physiological and proteomic analyses on artificially aged Brassica napus seed. Frontiers in Plant Science, v.6, n.112, p.1-11, 2015. https://www.frontiersin.org/articles/10.3389/fpls.2015.00112/full use, distribution, and reproduction in any medium, provided the original work is properly cited. 